\title{
NPK application in yellow pitaya seedlings grown on sand and organic compost
}

\section{Aplicação de NPK em mudas de pitaya amarela cultivadas em areia e composto orgânico}

\author{
Mônica Mariana Jorge Fratoni ${ }^{1}$; Kenneth Roger Rodrigues da Silva²; \\ Adônis Moreira $^{3 *}$
}

\begin{abstract}
Brazil is considered one of the largest fruit producers in the world and one of the fruit groups that has stood out is that of exotic ones, such as the yellow pitaya (Hylocereus megalanthus); however, there are only incipient studies related to this crop. The objective of this research was to evaluate the effect of an NPK fertilizer formulation $\left(\mathrm{N}-\mathrm{P}_{2} \mathrm{O}_{5}-\mathrm{K}_{2} \mathrm{O}: 8-20-20\right)$ on yellow pitaya grown in greenhouse conditions, using as substrate sand and organic compost $(3: 2)$. The experimental design was in randomized blocks, with six treatments and five replicates. The treatments consisted of the following rates of the NPK fertilizer: $0,200,250,300,350$, and $400 \mathrm{~g}$ per pot. The parameters evaluated were the rooting rate, height, diameter, fresh weight (FW), dry weight (DW), and nutrient content in cladodes. Although the application of $300 \mathrm{~g}$ per pot resulted in higher concentrations of $\mathrm{N}, \mathrm{P}, \mathrm{K}, \mathrm{Ca}, \mathrm{Mg}, \mathrm{S}, \mathrm{Fe}$, and $\mathrm{Zn}$, the sole use of the organic fertilizer (compost) mixed with sand was enough for adequate FW and DW yield of cladodes.
\end{abstract}

Key words: Hylocereus megalanthus. Mineral fertilizer. Greenhouse. Potting. Sand substrate.

\section{Resumo}

O Brasil é considerado um dos maiores produtores de frutas exóticas do mundo e o cultivo da pitaya amarela (Hylocereus megalanthus) tem se destacado, apesar de estudos relacionados ao manejo dessa cultura serem incipientes $\mathrm{O}$ presente estudo teve por objetivo avaliar os efeitos de doses do formulado $\mathrm{N}-\mathrm{P}_{2} \mathrm{O}_{5}-\mathrm{K}_{2} \mathrm{O}$ (NPK) na concentração 08-20-20 em mudas de pitaya amarela conduzidas em condições de casa de vegetação, contendo como substrato areia e composto orgânico $(3: 2, \mathrm{v}: \mathrm{v})$. O delineamento experimental foi o de blocos ao acaso com seis tratamentos e cinco repetições. Os tratamentos consistiram na aplicação das seguintes doses do formulado NPK (08-20-20): 0, 200, 250, 300, 350 e $400 \mathrm{~g}$ por vaso de $5 \mathrm{~L}$. As variáveis avaliadas foram taxa de enraizamento, altura, diâmetro, massa fresca (MF), massa seca (MS) da parte aérea e teor dos nutrientes dos cladódios. Apesar da aplicação de 300 g por vaso ter resultado em maior concentração de $\mathrm{N}, \mathrm{P}, \mathrm{K}, \mathrm{Ca}, \mathrm{Mg}, \mathrm{S}, \mathrm{Fe}$ e $\mathrm{Zn}$ nos cladódios de pitaya, a utilização de apenas adubo orgânico e areia mostrou-se suficiente para o incremento da MS e MF dos cladódios. Palavras-chave: Hylocereus megalanthus. Adubo mineral, Ambiente protegido, Substrato areia.

1 Eng $^{\text {a }}$ Agra , Discente, Curso de Doutorado, Programa de Pós-Graduação em Agronomia, Universidade Estadual de Londrina, UEL, Londrina, PR, Brasil. E-mail: moagrouel@yahoo.com.br

2 Discente, Curso de Graduação em Engenharia de Materiais, Universidade de São Carlos, UFSCAR, São Carlos, SP, Brasil. E-mail: kennth roger2010@hotmail.com

3 Pesquisador Dr., Empresa Brasileira de Pesquisa Agropecuária, EMBRAPA Soja, Londrina, PR, Brasil. E-mail: adonis.moreira@ embrapa.br

* Author for correspondence

Received: May 07, 2018 - Approved: Feb. 18, 2019 


\section{Introduction}

Brazil is the third largest producer of fruit in the world (FAO, 2018) and the cultivation of exotic fruits has a high agricultural potential, but there are still few studies referred to these plants, which have a promising consumer market. Among these exotic plants, the yellow pitaya (Hylocereus megalanthus) (MIZRAHI, 2014) presents great potential for cultivation and commercialization (TEL-ZUR et al., 2004). This plant is distributed geographically in several countries of South America, mainly in Bolivia, Peru, Ecuador, Colombia, and Venezuela (WEISS et al., 1995), and also in Central America (Costa Rica, Guatemala, and El Salvador) (DONADIO, 2009).

Depending on the substrate for seedling production and soil fertility, yellow pitaya may require fertilization rich in organic matter $(\mathrm{OM})$, nitrogen $(\mathrm{N})$, potassium $(\mathrm{K})$, and phosphorus (P) (ORTIZ-HERNANDEZ, 2000). Nitrogen is essential to stimulate the emission of roots and shoots and is required in all vegetative growth until the pre-flowering of plants (LUDERS, 2004), while $\mathrm{K}$ acts as an enzymatic activator or coenzyme and neutralizing anion. Potassium is also involved in the translocation of carbohydrates and the regulation of cell osmotic potential and stomata opening and closing (BUSSAKORN et al., 2003; BRITO et al., 2005; MARENCO; LOPES, 2011; DUARTE, 2013). Phosphorus participates in photosynthesis, respiration, storage and energy transfer, and cell division. This nutrient is important for fruit formation and flowering (MALAVOLTA, 2006; MARENCO; LOPES, 2011).

The pitaya fruit is characterized by the globulous or subglobulous shape, presenting external green color when immature and yellow or red when ripe. The fruit is covered by bracts, and some species present thorns in their bark (NERD; MIZRAHI, 1999). The pulp displays colors ranging from bright red-purple to white, with numerous dark edible seeds distributed throughout. The stem of the pitaya, called cladode, presents a triangular with spines, which are modified leaves (NUNES et al., 2014). The fruit has ample use and can be consumed in its fresh form or industrialized as juice, pulp, ice cream, and candy coloring (DONADIO, 2009). It also has medicinal value because it contains captin, a cardiac tonic, and its seeds have a laxative effect. Pitaya fruit contains few lipids and along with other fruits can aid in a balanced diet. In addition, it presents high amounts of bioactive compounds, mainly pigments and phenolic compounds, generally related to plant defense (NUNES et al., 2014).

The use of substrates as a technique of plant cultivation began in the 1930s; however, the interest in systems that use different substrates has only increased in recent years (ARRUDA et al., 2007; SALVADOR et al., 2013; PISSINATI et al., 2018). This technique of seedling cultivation has gained diffusion because it allows better utilization of nutrients, higher glue index, and better quality of seedlings. Besides, it facilitates the execution of cultural treatments (CALABRETTA et al., 1994) and protects plants from the possible presence of soil pathogens (FONTES et al., 2004). Studies on the fertilization management in yellow pitaya seedlings and its effect on yield are scarce. The present study had as objective to evaluate the effect of an NPK formulation| (8-20-20) added at different rates to a substrate containing organic compost and sand (2:3; $\mathrm{v}: \mathrm{v}$ ratio) in the initial development of yellow pitaya cladodes and nutritional status of the plant.

\section{Material and Methods}

The experiment was carried out in a greenhouse with polyethylene plastic cover located in the Center of Agricultural Sciences of the State University of Londrina (UEL), Londrina, Paraná State, where the geographical coordinates are latitude $23^{\circ} 23^{\prime} \mathrm{LS}$ and longitude $51^{\circ} 10^{\prime} \mathrm{LW}$. The climate is characterized as belonging to the Cfa group- subtropical humid (KÖPPEN; GEIGER, 1928), with an average temperature ranging from 18 to $22^{\circ} \mathrm{C}$. 
The experimental design was in randomized blocks with six rates of an NPK fertilizer $\left(\mathrm{N}_{-} \mathrm{P}_{2} \mathrm{O}_{5}\right.$ $\left.\mathrm{K}_{2} \mathrm{O} ; 8-20-20\right)$ and five replicates. The treatments were $0,200,250,300,350$, and $400 \mathrm{~g}$ per pot of the NPK formulation. The substrate used was $3 \mathrm{~L}$ of sand $\left[\mathrm{P}=4.8 \mathrm{mg} \mathrm{dm}^{-3}, \mathrm{~K}^{+}=0.2 \mathrm{cmol}_{\mathrm{c}} \mathrm{dm}^{-3}, \mathrm{H}^{+}+\mathrm{Al}^{3+}\right.$ $=1.5 \mathrm{cmol}_{\mathrm{c}} \mathrm{dm}^{-3}$, cation exchange capacity $(\mathrm{CEC})$ $\left.=1.7 \mathrm{cmol}_{\mathrm{c}} \mathrm{dm}^{-3}\right]$ and $2 \mathrm{~L}$ of an organic compound derived from plant remains $(\mathrm{pH}=8.1, \mathrm{OM}=40 \%, \mathrm{~N}$ $=0.8 \%, \mathrm{P}_{2} \mathrm{O}_{5}=0.3 \%, \mathrm{~K}_{2} \mathrm{O}=9.2 \%, \mathrm{Ca}=0.2 \%$, and $\mathrm{Mg}=0.2 \%)$. Micronutrients $(\mathrm{B}, \mathrm{Fe}, \mathrm{Mn}, \mathrm{Mo}, \mathrm{Zn}$, and $\mathrm{Cu}$ ) were applied via foliar using the fertilizer Rexolin $\mathrm{BRA}^{\circledR}\left(60 \mathrm{~g} \mathrm{~L}^{-1}, 20 \mathrm{~mL}\right.$ per plant) at the implantation. The seedlings used were obtained from an eight-year-old plant free of pathogens and initially produced by seed.

The plants were watered daily so that $70 \%$ of the total volume of pores (TVP) in the vessels was filled with water. At 145 days after planting (DAP), phytotechnical analyses were carried out, with the measurement of seedlings height $(\mathrm{cm})$, seedlings diameter at $10 \mathrm{~cm}$ of the soil $(\mathrm{cm})$, and rooting rate $(\%)$. After performing these measurements, each plant was placed in a Kraft paper bag and weighed immediately to obtain the fresh weight (FW). Subsequently, plants were placed in a forcedcirculation air oven at $55^{\circ} \mathrm{C}$ until reaching a constant mass to determine the dry weight (DW). Once dried, the cladodes were ground in a Willey mill to determine total $\mathrm{N}, \mathrm{P}, \mathrm{K}, \mathrm{Ca}, \mathrm{Mg}, \mathrm{S}, \mathrm{Cu}, \mathrm{Fe}, \mathrm{Mn}$, and Zn contents. After sulfuric digestion, the $\mathrm{N}$ content was obtained by the Kjeldahl microdistiller method (BREMNER; KEENEY, 1996). Total nutrient levels were assessed after nitric-perchloric digestion: total $\mathrm{P}$ contents were measured by the reduction of phosphomolybdate by ascorbic acid (BRAGA; DEFELIPO, 1974), total S by turbidimetry with barium chloride (BLANCHAR et al., 1965), K by flame photometry, and $\mathrm{Ca}, \mathrm{Mg}, \mathrm{Cu}, \mathrm{Fe}, \mathrm{Mn}$, and $\mathrm{Zn}$, by atomic absorption spectrophotometry (MALAVOLTA et al., 1997).
In order to verify the effects of NPK additions on the development of pitaya seedlings, the collected data were submitted to analysis of variance (ANOVA), F test, and regression at 5\% probability using the statistical program SISVAR $^{\circledR}$ version 5.3 (FERREIRA, 2010).

\section{Results and Discussion}

The rooting rate of cladodes cuttings was not influenced by NPK addition and was of $92 \%$ on average. This result is similar to that of Andrade et al. (2007), who reported a rooting rate of $100 \%$ when cultivating red pitaya on a substrate containing a mixture of soil, sand, and tanned corral manure (3:1:1, v:v:v ratio). The same was verified by Bastos et al. (2006), who studied the use of rooting inducers; they also obtained a high (98\%) glue index with the application of $3000 \mathrm{mg} \mathrm{L}^{-1}$ of indolebutyric acid (IBA) and $82 \%$ without the addition of IBA. These results are important and demonstrate the high degree of rooting of this species by the cutting technique, made in different types of substrates and under different management.

Regarding biomass yield of yellow pitaya, it was verified that the FW of cladodes presented a quadratic response to the NPK fertilizer (Figure 1 ), with the maximum estimated yield obtained at a rate of $63.8 \mathrm{~g}$ per pot, while DW was negatively affected by this fertilization, with the highest yield in the treatment without fertilizer application. The results obtained showed that the use of a substrate containing only sand and organic compost was enough to produce yellow pitaya seedlings of quality, being unnecessary the application of formulations intended to stimulate growth and to increase FW and DW. In agreement with our results, Silva et al. (2006) reported that the use of sand, tanned corral manure, and soil in the ratio 1:1:3 (v:v:v) was the most adequate to increase dry weight (DW) yield of red pitaya (Hylocereus undatus Haw). 
Figure 1. Fresh weight (FW) and dry weight (DW) of yellow pitaya (Hylocereus megalanthus) cladodes as a function of six rates of NPK (8:20:20) fertilization. Plants were grown on a substrate containing sand and an organic compound.

* Significant at $5 \%$ probability.

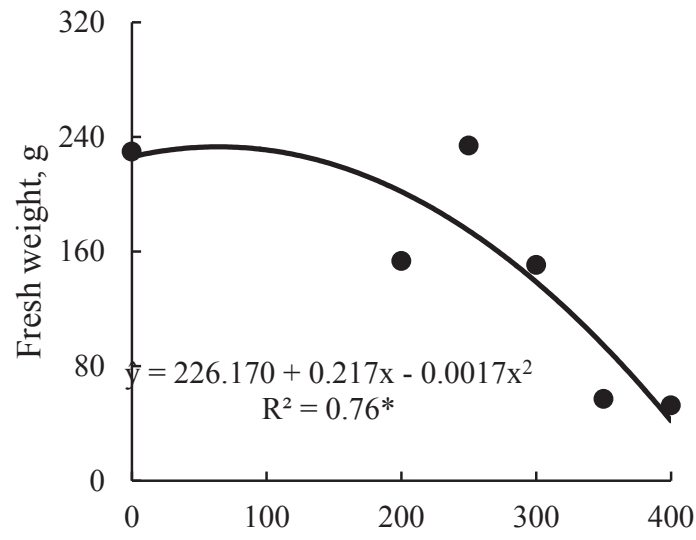

However, depending on the substrate used, supplementation with fertilizers may be necessary, as verified by Fernandes (2016). This author reported a positive effect on DW yield with the application of phosphate fertilizer in pitaya when cultivated in a Typic Oxisol (dystrophic Red Latosol), with 360 $\mathrm{g} \mathrm{kg}^{-1}$ clay and base saturation (V) of 5.1\%. Another positive effect of fertilizer application was obtained by $\mathrm{Ke}(1997)$ under the edaphoclimatic conditions of Vietnam; this researcher applied $20 \mathrm{~g}$ of $\mathrm{P}_{2} \mathrm{O}_{5}$ per plant during the first two years of cultivation and covered with $200 \mathrm{~g}$ of NPK (16-16-8); this treatment increased the DW yield of cladodes.

In addition to the characteristics of each substrate, such differences in the results may also be due to the great genetic variability within the same species and among plants with different genotypic characteristics (JUNQUEIRA et al., 2010). Regarding the height and circumference of cladodes, in spite of a small reduction observed with increasing NPK rates applied to the substrate, these parameters were not significantly affected by the treatments and ranged between 0 and $400 \mathrm{~g}$ per pot of NPK from 18.3 - to $26.6 \mathrm{~cm}$ and 6.7 - to 8.9 $\mathrm{cm}$, respectively.

The N, P, K, Ca, Mg, S, Cu, Fe, Mn, and $\mathrm{Zn}$ concentrations in cladodes varied significantly on

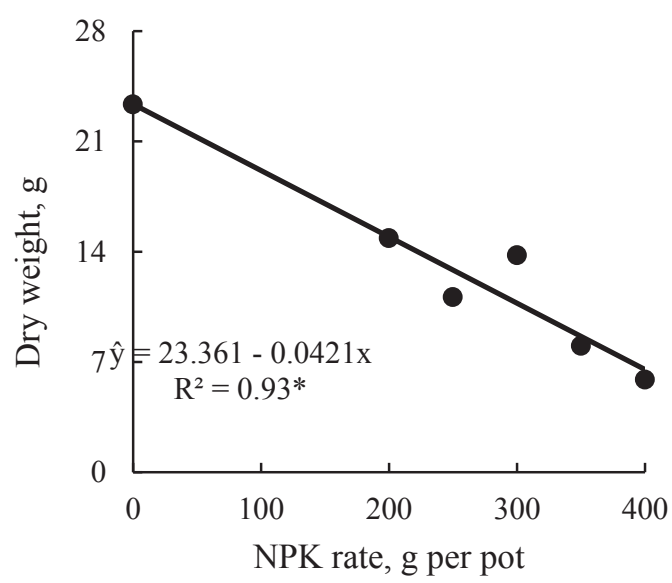

comparing the different NPK formulation rates applied (Figures 2, 3, 4, and 5). It was observed that the highest $\mathrm{N}\left(21.5 \mathrm{~g} \mathrm{~kg}^{-1}\right), \mathrm{P}\left(14.4 \mathrm{~g} \mathrm{~kg}^{-1}\right)$, and $\mathrm{K}\left(65.6 \mathrm{~g} \mathrm{~kg}^{-1}\right)$ concentrations were obtained at estimated fertilizer rates of 198, 163, and $400 \mathrm{~g}$ per pot (Figure 2), while for $\mathrm{Ca}, \mathrm{Mg}$, and $\mathrm{S}$, the estimated rates that resulted in maximum concentrations $\left(18.5,9.7\right.$, and $\left.2.0 \mathrm{~g} \mathrm{~kg}^{-1}\right)$ were 150 and $240 \mathrm{~g}$ of NPK per pot, respectively. This demonstrates that in the cladodes of the yellow pitaya, the sequence of nutrient accumulation is $\mathrm{K}>\mathrm{N}>\mathrm{Ca}>\mathrm{P}>\mathrm{Mg}>\mathrm{S}$.

These results on the nutritional demand of yellow pitaya agree with those reported by Moreira et al. (2011), who assessed organic fertilization in red pitaya cladodes. They obtained similar sequences in $\mathrm{N}, \mathrm{P}$, and $\mathrm{K}$ content, but their values varied from 11- to $16 \mathrm{~g} \mathrm{~N} \mathrm{~kg}^{-1}, 1.9$ - to $3.3 \mathrm{~g} \mathrm{P} \mathrm{kg}^{-1}$, and 23 - to $26 \mathrm{~g} \mathrm{~K} \mathrm{~kg}^{-1}$, values well below those obtained in the present study (Figure 2). Given the few studies carried out with this crop, these results are not conclusive (MOREIRA et al., 2011). Likewise, it should be mentioned the variability of the genetic material and, especially, of the substrate type used, as verified by the work of Fernandes (2016), who evaluated phosphate fertilization in yellow pitaya and found $\mathrm{N}, \mathrm{P}$, and $\mathrm{K}$ values of 2 - to $9 \mathrm{~g} \mathrm{~kg}^{-1}, 0.62$ $\mathrm{g} \mathrm{kg}^{-1}$, and $6.43 \mathrm{~g} \mathrm{~kg}^{-1}$, respectively. 
Figure 2. N, P, and K content of yellow pitaya (Hylocereus megalanthus) cladodes as a function of six rates of NPK (8:20:20) fertilization. Plants were grown on a substrate containing sand and an organic compound. * Significant at $5 \%$ probability.
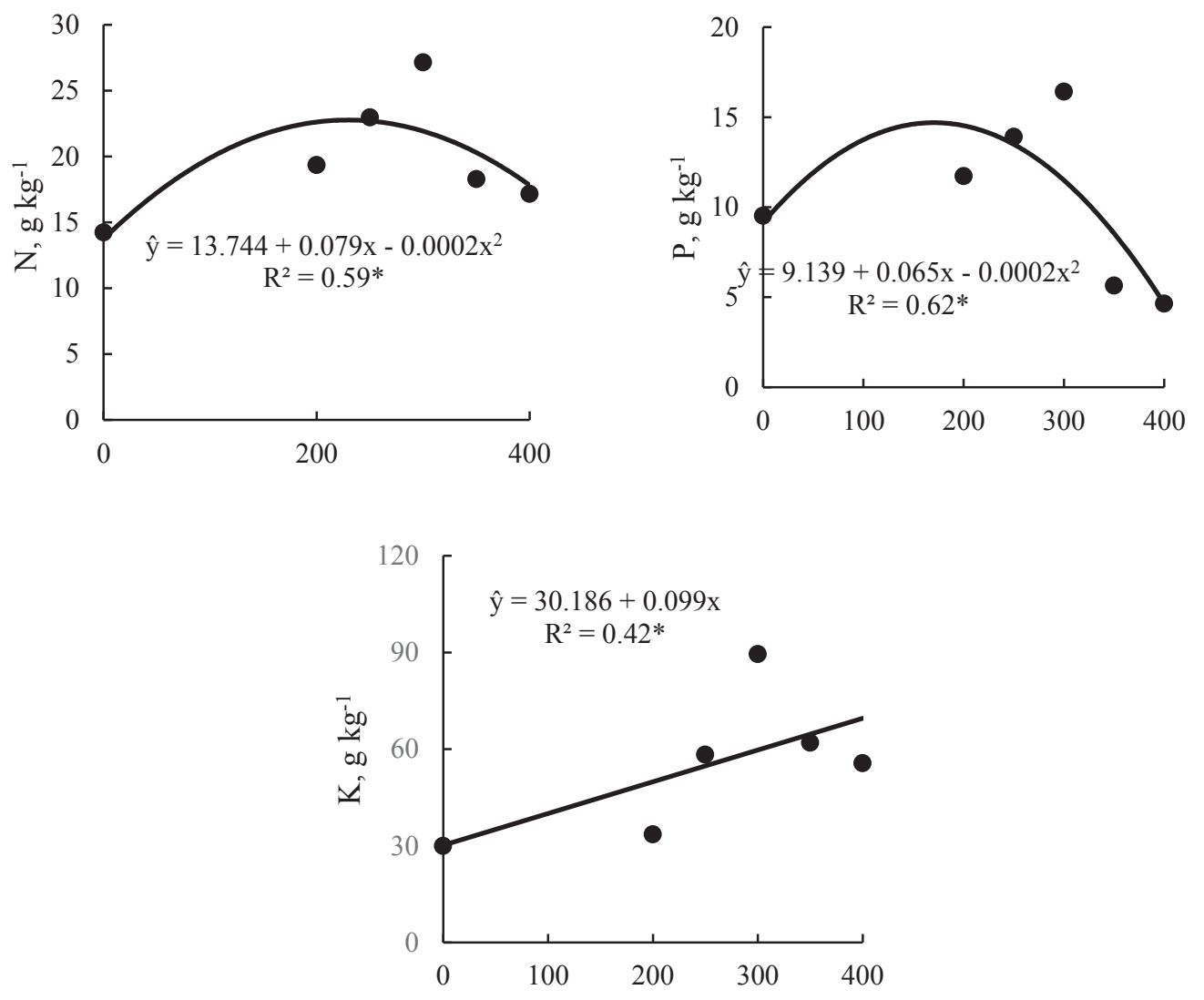

NPK rates, g per pot

This variability in nutrient concentrations was also verified in the study of Guzmán (1994), in which applications of $\mathrm{N}$ and $\mathrm{P}$ in pitaya cultivation resulted in a positive response, and in the study of Hernández (2000), who applied N, P, and K.

Phosphorus (P) is one of the most required nutrients in the early stages of plant development and participates in cell division and photosynthesis, and provides initial formation and root development (MALAVOLTA et al., 1997; EPSTEIN; BLOOM, 2006), whereas $\mathrm{K}$ acts in the transport of photoassimilates to storage organs such as fruits, and participates in the formation of sugars, promoting improvements in their size (FERNANDES, 2016). Due to the high demand of these nutrients by pitaya, Tri et al. (2000) suggested to apply them in adult plants but only if soils have low natural fertility
(MOREIRA et al., 2017); the rates recommended were $300 \mathrm{~g}$ of $\mathrm{K}_{2} \mathrm{O}, 540 \mathrm{~g}$ of $\mathrm{N}, 720 \mathrm{~g}$ of $\mathrm{P}_{2} \mathrm{O}_{5}$, and $20 \mathrm{~kg}$ of cattle manure per plant, divided into four applications during the year.

$\mathrm{Ca}$ and $\mathrm{Mg}$ concentrations in cladodes also were significantly different according to NPK rates applied (Figure 3). The highest Ca content (18.5 g $\mathrm{kg}^{-1}$ ) was obtained with an estimated fertilizer rate of $150 \mathrm{~g} \mathrm{pot}^{-1}$, while $\mathrm{Mg}$ content decreased linearly from 9.7- to $5.9 \mathrm{~g} \mathrm{~kg}^{-1}$ (MALAVOLTA, 2006). The increase in the amount of $\mathrm{K}$ applied diminished $\mathrm{Mg}$ content, making evident the effect of the interionic competition for the same uptake site described by Marschner (1995) and Malavolta (2006) reported that $\mathrm{K}$ accumulation decreases $\mathrm{Ca}, \mathrm{P}$, and $\mathrm{S}$. Fernandes (2016), in studies on $\mathrm{P}$ and $\mathrm{K}$ fertilization in pitaya, reported values of $2.6 \mathrm{~g} \mathrm{~kg}^{-1}$ of $\mathrm{Ca}$ and 1.7 
$\mathrm{g} \mathrm{kg}^{-1}$ of $\mathrm{Mg}$ in yellow pitaya, values well below those registered in the present study, regardless of the NPK rates used (Figure 3). On comparing our results with those of the work mentioned, it may be noticed that at the highest NPK rate we applied (400 $\mathrm{g}$ per pot), Ca and $\mathrm{Mg}$ contents (13.77 $\mathrm{g} \mathrm{kg}^{-1}$ and 4.68 $\mathrm{g} \mathrm{kg}^{-1}$, respectively) were higher than those found by the above-mentioned author. Sulfur content also significantly varied depending on the rate of NPK application (Figure 3); the highest $\mathrm{S}$ level in pitaya cladodes $\left(3.2 \mathrm{~g} \mathrm{~kg}^{-1}\right)$ was obtained with an estimated rate of $250 \mathrm{~g}$ per pot of the formulation.

Figure 3. $\mathrm{Ca}, \mathrm{Mg}$, and $\mathrm{S}$ content in yellow pitaya (Hylocereus megalanthus) cladodes as a function of six rates of NPK (8:20:20) fertilization. Plants were grown on a substrate containing sand and an organic compound. * Significant at $5 \%$ probability.
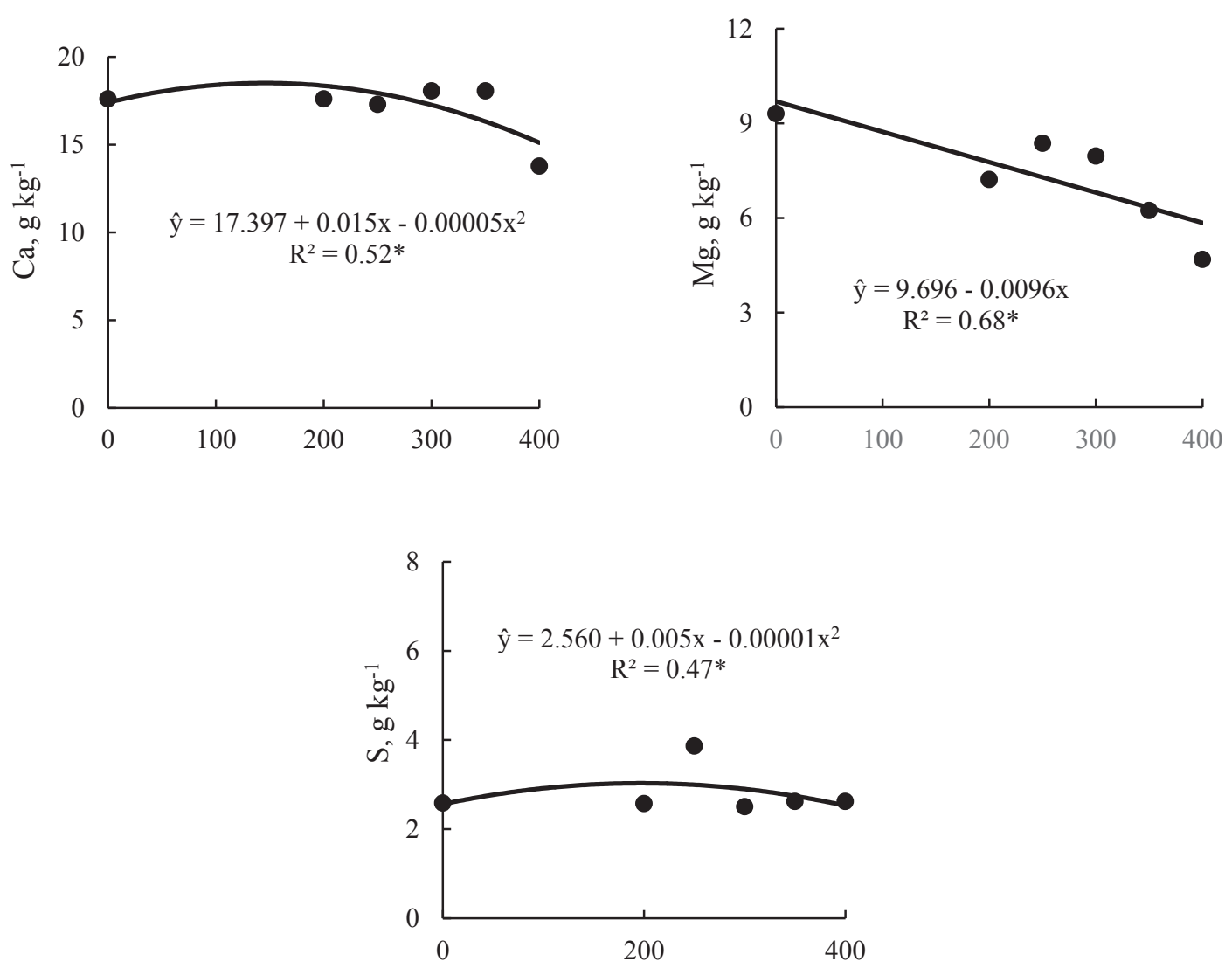

NPK rates, g per pot

$\mathrm{Cu}, \mathrm{Fe}, \mathrm{Mn}$, and $\mathrm{Zn}$ content also significantly differed depending on the NPK rate applied (Figures 4 and 5). The content of $\mathrm{Cu}$ in pitaya cladodes increased linearly with increasing NPK rates, and the inverse occurred for $\mathrm{Fe}$ and $\mathrm{Zn}$. Cu ranged from 8.9 - to $17.7 \mathrm{mg} \mathrm{kg}^{-1}$, Fe from 500.0 - to $198.8 \mathrm{mg} \mathrm{kg}^{-}$ 1 , and $\mathrm{Zn}$ from 112.3 - to $76.3 \mathrm{mg} \mathrm{kg}^{-1}$. In studies of phosphate fertilization in yellow pitaya, Fernandes (2016) found micronutrient levels in cladodes which ranged from 8- to $10 \mathrm{mg} \mathrm{kg}^{-1}$ for $\mathrm{Cu}, 200$ - to
$400 \mathrm{mg} \mathrm{kg}^{-1}$ for $\mathrm{Mn}, 140$ - to $200 \mathrm{mg} \mathrm{kg}^{-1}$ for $\mathrm{Fe}$, and 19- to $35 \mathrm{mg} \mathrm{kg}^{-1}$ for $\mathrm{Zn}$. The contents of these last two nutrients ( $\mathrm{Zn}$ and $\mathrm{Fe}$ ) differ from those obtained in the present study in all treatments, but $\mathrm{Cu}$ and Mn contents tend to coincide (Figures 4 and 5). We observed the following sequence for micronutrient contents in the cladodes: $\mathrm{Fe}>\mathrm{Mn}>\mathrm{Zn}>\mathrm{Cu}$. Factors such as genetic material and the type of substrate used may have influenced and accounted for the discrepancies described in this study. 
Figure 4. $\mathrm{Cu}$ and Fe content in yellow pitaya (Hylocereus megalanthus) cladodes as a function of six rates of NPK $(8: 20: 20)$ fertilization. Plants were grown on a substrate containing sand and an organic compound. * Significant at $5 \%$ probability.
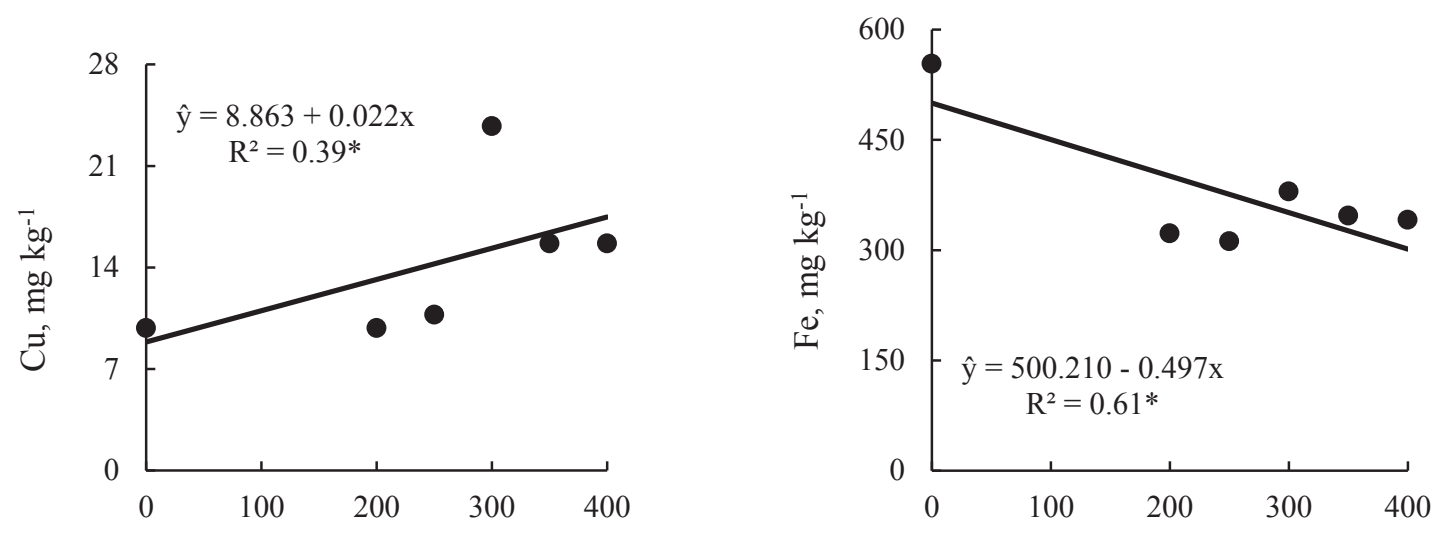

Figure 5. Mn and Zn contents in yellow pitaya (Hylocereus megalanthus) cladodes as a function of six rates of NPK (8:20:20) fertilization. Plants were grown on a substrate containing sand and an organic compound. * Significant at $5 \%$ probability.

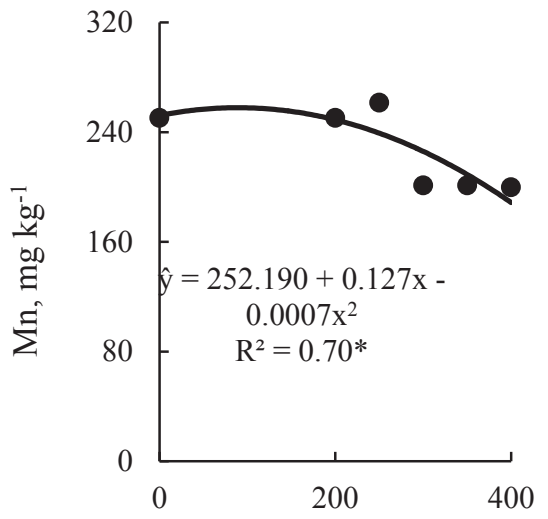

\section{Conclusion}

The height, diameter, and glue index of yellow pitaya cladodes were not affected by the addition of the NPK formulation (8-20-20) evaluated, at any rate.

The use of the organic compost and sand in the ratio 2:3 (v:v) was sufficient for the increase in fresh weight (FW) and dry weight (DW) yield of yellow pitaya plants.

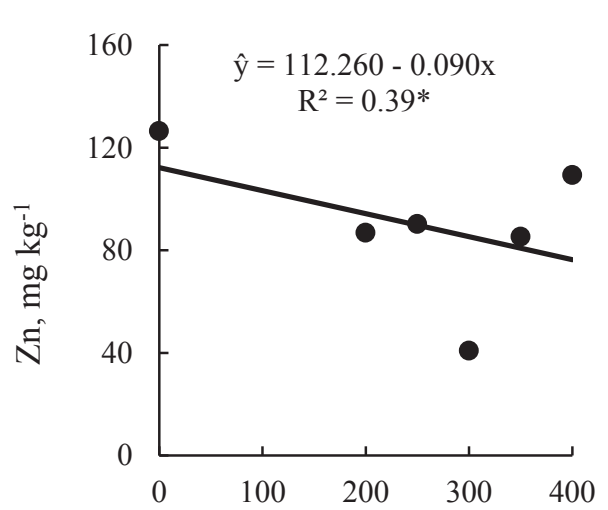

NPK rates, g per pot

Yellow pitaya presented the following sequence regarding macronutrients demands: $\mathrm{K}>\mathrm{N}>\mathrm{Ca}>\mathrm{P}>\mathrm{Mg}>\mathrm{S}$, whereas the sequence was $\mathrm{Fe}>\mathrm{Mn}>\mathrm{Zn}>\mathrm{Cu}$ for the micronutrients.

\section{References}

ANDRADE, R. A.; MARTINS, A. B. G.; SILVA, M. T. H. Influência da fonte de material e do tempo de cura na propagação vegetativa da pitaya vermelha (Hylocereus 
undatus Haw). Revista Brasileira de Fruticultura, Jaboticabal, v. 29, n. 1, p. 183-186, 2007.

ARRUDA, M. R.; PEREIRA, J. C. R.; MOREIRA, A.; TEIXEIRA, W. G. Enraizamento de estacas herbáceas de guaranazeiro em diferentes substratos. Ciência $e$ Agrotecnologia, Lavras, v. 31, n. 1, p. 236-241, 2007.

BASTOS, D. C.; PIO, R.; SCARPARE FILHO, J. A.; LIBARDI, M. N.; ALMEIDA, L. F. P.; GALUCHI, T. P. D.; BAKKE, S. T. Propagação da pitaya vermelha por estaquia. Ciência e Agrotecnologia, Lavras, v. 30, n. 6, p. 1106-1109, 2006.

BLANCHAR, R. W.; REHM, G.; CALDWELL, A. C. Sulfur in plant material by digestion with nitric and perchloric acid. Soil Science Society of America Journal, Madison, v. 29, n. 1, p. 71-72, 1965.

BRAGA, J. M.; DEFELIPO, B. Determinação espectrofotométrica de fósforo em extratos de solos e plantas. Revista Ceres, Viçosa, MG, v. 21, n. 113, p. 73$85,1974$.

BREMNER, J. M.; KEENEY, D. R. Determination and isotope-ratio analysis of different forms of nitrogen in soils 3: Exchangeable ammonium, nitrate, and nitrite by extraction-distillation methods. Soil Science Society of America Journal, Madison, v. 30, n. 5, p. 577-582, 1996.

BRITO, M. E. B.; MELO, A.; LUSTOSA, J. P. O.; ROCHA, M. B.; VIÉGAS, P. R. A.; HOLANDA, F. S. R. Rendimentos e qualidade da fruta maracujazeiro-amarelo adubado com potássio, esterco de frango e de ovino. Revista Brasileira de Fruticultura, Jaboticabal, v. 27, n. 2, p. 260-263, 2005.

BUSSAKORN, S. M.; DANIEL, P. S.; MICHAEL, T. T.; MARK, R. T. A review of potassium nutrition in grapevines with special emphasis on berry accumulation. Australian Journal of Grape and Wine Research, Milton, v. 9, n. 3, p. 154-168, 2003. DOI: 10.1111/j.17550238.2003.tb00265.x

CALABRETTA, C.; NUCIFORA, M. T.; FERRO, B.; NATALE, V. New techniques for the cultivation and defense of tomato crops in cold greenhouses in the area Ragusa (Sicily). Acta Horticulturae, Leuven, v. 59, n. 361, p. 530-544, 1994. DOI: 10.17660/ ActaHortic.1994.361.59

DONADIO, L. C. Pitaya. Revista Brasileira de Fruticultura, Jaboticabal, v. 31, n. 3, p. 637-929, 2009.

DUARTE, M. H. Armazenamento e qualidade de pitaia (Hylocereus undatus (Haw.) Britton \& Rose, submetida à adubação orgânica. 2013. Dissertação (Mestrado em Agroquímica) - Universidade Federal de Lavras, Lavras.
EPSTEIN, E.; BLOOM, A. J. Nutrição mineral de plantas: princípios e perspectivas. Londrina: Editora Planta, 2006. 403 p.

FERNANDES, D. R. Adubação fosfatada e potássica no cultivo de pitaya. 2016. Dissertação (Mestrado em Produção Vegetal) - Universidade Federal dos Vales do Jequitinhonha e Mucuri, Diamantina.

FERREIRA, D. F. SISVAR - sistema de análise de variância. Versão 5.3. Lavras: UFLA, 2010.

FONTES, P. C. R.; LOURES, J. L.; GALVÃO, J. C.; CARDoso, A. A.; MANTOVANI, E.C. Produção e qualidade do tomate produzido em substrato, no campo e em ambiente protegido. Horticultura Brasileira, Brasília, v. 22, n. 3, p. 614-619, 2004.

FOOD AND AGRICULTURE ORGANIZATION OF THE UNITED NATIONS - FAO. Statistical Yearbook. Roma: FAO, 2018. Available at: http://www.fao.org/3/ai3590e.pdf. Accessed at: 3 set. 2018.

GUZMÁN, R. Fertilización de la pitahaya. In: ENCUENTRO NACIONAL DEL CULTIVO DE LA PITAHAYA, 1., 1994, San Marcos. Memorias... San Marcos: INTA, 1994. p. 80-82.

HERNÁNDEZ, Y. D. O. Hacia el conocimiento y la conservación de la pitahaya. Oaxaca: IPN-SIBEJCONACYT-FMCN, 2000. 124 p.

JUNQUEIRA, K. P.; FALEIRO, F. G.; BELLON, G.; JUNQUEIRA, N. T. V.; FONSECA, K. G.; LIMA, C. A.; SANTOS, E. C. Variabilidade genética de acessos de pitaya com diferentes níveis de produção por meio de marcadores RAPD. Revista Brasileira de Fruticultura, Jaboticabal, v. 32, n. 3, p. 840-846, 2010.

KE, N. V. Dragon fruit. Ho Chi Minh City: Agriculture Publisher, 1997. 220 p.

KÖPPEN, W.; GEIGER, R. Klimate der erde. Gotha: Verlag Justus Perthes, 1928. 56 p.

LUDERS, L. The pitaya or dragon fruit (Hylocereus undatus). Darwin: University of Darwin, 2004. 5 p.

MALAVOLTA, E. Manual de nutrição mineral de plantas. São Paulo: Agronômica Ceres, 2006. 638 p.

MALAVOLTA, E.; VITTI, G. C.; OLIVEIRA, S. A. Avaliação do estado nutricional das plantas: princípios e aplicações. 2. ed. Piracicaba: Potafos, 1997. 281 p.

MARENCO, R. A.; LOPES, N. F. Fisiologia vegetal. 3. ed. Viçosa, MG: UFV, 2011. 486 p.

MARSCHNER, H. Mineral nutrition of higher plants. $2^{\text {th }}$ ed. London: Academic Press, 1995. 889 p. 
MIZRAHI, Y. Vine-Cacti pitayas-the new crops of the world. Revista Brasileira de Fruticultura, Jaboticabal, v. 36 , n. 1, p. 124-138, 2014. DOI: 10.1590/0100-2945$452 / 13$

MOREIRA, A.; MOTTA, A. C. V.; COSTA, A.; MUNIZ, A. S.; CASSOL, L. C.; ZANÃO JUNIOR, L. A.; BATISTA, M. A.; MÜlLER, M. M. L.; HAGER, N.; PAULETTI, V. Manual de adubação e calagem para $o$ Estado do Paraná. Curitiba: NEPAR-SBCS, 2017. 482 p.

MOREIRA, R. A.; RAMOS, J. D.; ARAUJO, N. A.; MARQUES, V. B. Produção e qualidade de frutos de pitaya vermelha com adubação orgânica e granulado bioclástico. Revista Brasileira de Fruticultura, Jaboticabal, v. 33, n. 1, p. 762-766, 2011.

NERD, A.; MIZRAHI, Y. Effect of ripening stage on fruit quality after storage of yellow pitaya. Postharvest Biology and Technology, Dordrecht, v. 15, n. 2, p. 99105, 1999. DOI: 10.1016/S0925-5214(98)00080-5

NUNES, E. N.; SOUSA, A. S. B.; LUCENA, C. M.; SILVA, S. M.; LUCENA, R. F. P.; ALVES, C. A. B.; ALVES, R. E. Pitaia (Hylocereus sp.): uma revisão para o Brasil. Gaia Scientia, João Pessoa, v. 8, n. 1, p. 90-98, 2014.

ORTIZ-HERNANDEZ, Y. D. Hacia el conocimiento y conservación de la Pitahaya (Hylocereus sp.). Oaxaca: IPN-SIBEJ-Conacyt- FMCN, 2000. 124 p.
PISSINATTI, A.; MOREIRA, A.; SANTORO, P. H. Growing media for horticultural bedding plants yield under agriculture organic systems. Communications in Soil Science and Plant Analysis, London, v. 49, n. 13, p. 1660-1670,2018. DOI: 10.1080/00103624.2018.1474904

SALVADOR, J. O.; MOREIRA, A.; MARCANTE, N. C. Waste use as substrate to yield guava seedlings. Semina: Ciências Agrárias, Londrina, v. 34, n. 6, p. 2793-2802, 2013. DOI: $10.5433 / 1679-0359.2013 v 34 n 6$ p2793

SILVA, M. T. H.; MARTINS, A. B. G.; ANDRADE, R. A. Enraizamento de estacas de pitaya vermelha em diferentes substratos. Caatinga, Mossoró, v. 19, n. 1, p. 61-64, 2006.

TEL-ZUR, N.; ABBO, S.; BAR-ZVI, D.; MIZRAHI, Y. Clone identification and genetic relationship among vine cacti from the genera Hylocereus and Selenicereus based on RAPD analysis. Scientia Horticulturae, Amsterdam, v. 100, n. 4, p. 279-289, 2004. DOI: 10.1016/j. scienta.2003.09.007

TRI, T. M.; HONG, B. T. M.; CHAU, N. M. Effect of $\mathrm{N}, \mathrm{P}$ and $\mathrm{K}$ on yield and quality of dragon fruit. In: ANNUAL REPORT OF FRUITS RESEARCH, 1., 2000, Proceedings... Southern Fruit Research Institute. Agriculture Publishers. Ho Chi Mihn City, 2000.

WEISS, J.; SCHEINVAR, L.; MIZRAHI, Y. Selenicereus megalanthus (the yellow pitaya), a climbing cactus from Colombia and Peru. Cactus and Succulent Journal, Claremont, v. 67, n. 5, p. 280-283, 1995. 
